\title{
Front Matter: Volume 8469
}

, "Front Matter: Volume 8469," Proc. SPIE 8469, Solar Hydrogen and Nanotechnology VII, 846901 (13 November 2012); doi: 10.1117/12.2011785

SPIE Event: SPIE Solar Energy + Technology, 2012, San Diego, California, United SPIE. States 


\section{PROCEEDINGS OF SPIE}

\section{Solar Hydrogen and Nanotechnology VII}

Lionel Vayssieres

Editor

13-16 August 2012

San Diego, California, United States

Sponsored and Published by

SPIE 
The papers included in this volume were part of the technical conference cited on the cover and title page. Papers were selected and subject to review by the editors and conference program committee. Some conference presentations may not be available for publication. The papers published in these proceedings reflect the work and thoughts of the authors and are published herein as submitted. The publisher is not responsible for the validity of the information or for any outcomes resulting from reliance thereon.

Please use the following format to cite material from this book:

Author(s), "Title of Paper," in Solar Hydrogen and Nanotechnology VII, edited by Lionel Vayssieres, Proceedings of SPIE Vol. 8469 (SPIE, Bellingham, WA, 2012) Article CID Number.

ISSN: 0277-786X

ISBN: 9780819491862

Published by

SPIE

P.O. Box 10, Bellingham, Washington 98227-0010 USA

Telephone +1 3606763290 (Pacific Time) · Fax +1 3606471445

SPIE.org

Copyright (C) 2012, Society of Photo-Optical Instrumentation Engineers.

Copying of material in this book for internal or personal use, or for the internal or personal use of specific clients, beyond the fair use provisions granted by the U.S. Copyright Law is authorized by SPIE subject to payment of copying fees. The Transactional Reporting Service base fee for this volume is $\$ 18.00$ per article (or portion thereof), which should be paid directly to the Copyright Clearance Center (CCC), 222 Rosewood Drive, Danvers, MA 01923. Payment may also be made electronically through CCC Online at copyright.com. Other copying for republication, resale, advertising or promotion, or any form of systematic or multiple reproduction of any material in this book is prohibited except with permission in writing from the publisher. The CCC fee code is 0277-786X/12/\$18.00.

Printed in the United States of America.

Publication of record for individual papers is online in the SPIE Digital Library.

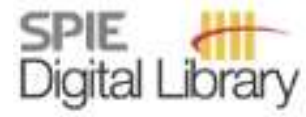

SPIEDigitalLibrary.org

Paper Numbering: Proceedings of SPIE follow an e-First publication model, with papers published first online and then in print and on CD-ROM. Papers are published as they are submitted and meet publication criteria. A unique, consistent, permanent citation identifier (CID) number is assigned to each article at the time of the first publication. Utilization of CIDs allows articles to be fully citable as soon as they are published online, and connects the same identifier to all online, print, and electronic versions of the publication. SPIE uses a six-digit CID article numbering system in which:

- The first four digits correspond to the SPIE volume number.

- The last two digits indicate publication order within the volume using a Base 36 numbering

system employing both numerals and letters. These two-number sets start with 00, 01, 02, 03, 04, $05,06,07,08,09,0 A, 0 B \ldots 0 Z$, followed by 10-1Z, 20-2Z, etc.

The CID Number appears on each page of the manuscript. The complete citation is used on the first page, and an abbreviated version on subsequent pages. Numbers in the index correspond to the last two digits of the six-digit CID Number. 


\section{Contents}

$\checkmark$ Conference Committee

NOVEL SYNTHESIS, MATERIALS AND DEVICE FABRICATION ॥

846900 Syngas production by thermochemical conversion of $\mathrm{CO}_{2}$ and $\mathrm{H}_{2} \mathrm{O}$ mixtures using a hightemperature heat pipe based reactor [8469-23]

H. Pearlman, C.-H. Chen, Advanced Cooling Technologies, Inc. (United States)

NOVEL TIO2-BASED NANOPHOTOCATALYSTS FOR SOLAR HYDROGEN GENERATION I

$84690 Q \quad$ Chemically induced electric field: flat band potential engineering [8469-25]

T. Bak, Univ. of Western Sydney (Australia); Z. Guo, Univ. of Wollongong (Australia); W. Li, Univ. of Western Sydney (Australia); A. J. Atanacio, Univ. of Western Sydney (Australia) and Australian Nuclear Science and Technology Organisation (Australia); J. Nowotny, Univ. of Western Sydney (Australia)

NOVEL TIO2-BASED NANOPHOTOCATALYSTS FOR SOLAR HYDROGEN GENERATION III

8469 0X Study on optoelectronic properties of (sulfur, transition metal) co-doped $\mathrm{TiO}_{2}$ using first principle calculation [8469-32]

S. Arab, R. K. Lake, Lab for Terascale and Terahertz Electronics (United States)

Author Index 
Proc. of SPIE Vol. $8469846901-4$ Downloaded From: https://www.spiedigitallibrary.org/conference-proceedings-of-spie on 26 Apr 2023
Terms of Use: https://www.spiedigitallibrary.org/terms-of-use 


\section{Conference Committee}

Symposium Chair

Martha Symko-Davies, National Renewable Energy Laboratory

(United States)

Conference Chair

Lionel Vayssieres, Xi'an Jiaotong University (China)

Conference Program Committee

Hironori Arakawa, Tokyo University of Science (Japan)

Jan Augustynski, University of Warsaw (Poland)

Michael Grätzel, Ecole Polytechnique Fédérale de Lausanne (Switzerland)

Jinghua Guo, Lawrence Berkeley National Laboratory (United States)

Hicham Idriss, University of Aberdeen (United Kingdom) and SABIC (Saudi Arabia)

Claude Levy-Clement, Centre National de la Recherche Scientifique (France)

Frank E. Osterloh, University of California, Davis (United States)

Yasuhiro Tachibana, RMIT University (Australia)

John A. Turner, National Renewable Energy Laboratory

(United States)

Heli Wang, National Renewable Energy Laboratory (United States)

Gunnar Westin, Uppsala University (Sweden)

Upul Wijayantha, Loughborough University (United Kingdom)

Jin Zhang, University of California, Santa Cruz (United States)

Session Chairs

1 Solar Hydrogen and Nanotechnology

Lionel Vayssieres, Xi'an Jiaotong University (China)

2 Advances in Iron Oxide-based Nanophotocatalysts for Solar Hydrogen Generation I

Sanjay Mathur, Universität zu Köln (Germany)

3 Advances in Iron Oxide-based Nanophotocatalysts for Solar Hydrogen Generation II

Craig A. Grimes, The Pennsylvania State University (United States) 
4 Advances in Iron Oxide-based Nanophotocatalysts for Solar Hydrogen Generation III

Dunwei Wang, Boston College (United States)

5 Spectroscopy and Electronic Structure of Nanophotocatalysts for Solar Hydrogen Generation I

Lionel Vayssieres, Xi'an Jiaotong University (China)

6 Spectroscopy and Electronic Structure of Nanophotocatalysts for Solar Hydrogen Generation II

Clemens Heske, University of Nevada, Las Vegas (United States)

7 Novel Synthesis, Materials and Device Fabrication I

Heli Wang, National Renewable Energy Laboratory (United States)

8 Novel Synthesis, Materials and Device Fabrication II Gunnar Westin, Uppsala University (Sweden)

9 Novel $\mathrm{TiO}_{2}$-based Nanophotocatalysts for Solar Hydrogen Generation I

Yasuhiro Tachibana, RMIT University (Australia)

10 Novel $\mathrm{TiO}_{2}$-based Nanophotocatalysts for Solar Hydrogen Generation II

Jin Zhang, University of California, Santa Cruz (United States)

11 Novel $\mathrm{TiO}_{2}$-based Nanophotocatalysts for Solar Hydrogen Generation III

Lionel Vayssieres, Xi'an Jiaotong University (China) 